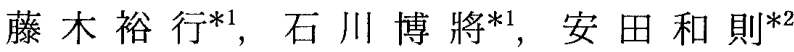

\title{
Contact Analysis of Artificial Knee Joint during Gait Movement
}

\author{
Hiroyuki FUJIKI, Hiromasa ISHIKAWA and Kazunori YASUDA
}

\begin{abstract}
Ultrahigh-molecular-weight polyethylene (UHMWPE) is used for the material of the contact surface in artificial knee joints, but the wear of this material becomes a serious problem to extend the life of the joint. In order to understand the wear mechanism of the UHMWPE in gait movement, the cyclic contact behavior of the UHMWPE is analyzed using the constitutive equation for cyclic plasticity because the UHMWPE is subjected to cyclic contact deformation during gait movement. In this analysis, the contact pressure distribution which is determined from the simple indentation analysis of femoral and tibial components is translated on the UHMWPE, changing its value so as to simulate the realistic movement of the joint. For the analytical model, the posterior cruciate ligament $(\mathrm{PCL})$ retention-type artificial knee joint is employed. As a result, it is clarified that local deformation is caused in this artificial knee joint, and the effect of the stress history, to which the UHMWIE has been subjected, on the wear machanism of the UHMWPE is significant.
\end{abstract}

Key Words: PCL-Retention-Type Artificial Knee Joint, Ultrahigh-Molecular-Weight Polyethylene, Cyclic Plasticity, FEM, Wear, Biotribology

\section{1. 緒言}

現在, 変形性:膝関節症や慢性関節リウマチ膝などの 重度な膝関節疾患に対して, 人工膝関節置換術が行わ れている.この人、膝関節の接触面材料として超高分 子量ポリエチレン (以下 UHMWPEとする) が一般的 に使用されているが，人二膝関節の寿命を考えた場合， このUHMWPE の摩耗に起因して骨吸収が生じ，こ れにより人て㯟関節の緩みとなる苜(2) ことが多く,よ り長寿命の人匚膝関節を開発するためにUHMWPE の耐摩耗性改良が強く望まれている。

この改良を性指してさまざまな研究が行われている が, 著者らは才学的にUHMWPEの接触変形挙動を 解析することがその摩耗特性を明らかにすることの第 一段階と考えた。そしてこれまでに繰返し塑性構成式 を組込んだ弾塑性有限要素法を用い, 繰返し接触を受 けるUHMWPE 平板の変形挙動を解析した ${ }^{(3)}$.また, 摩擦方向が UHMWPE 摩耗発生のメカニズムに及ほ す影響についても検討してきた ${ }^{(4)}$.その結果, 単純な

* 原稿受付 汗成 6 脌 6 月 30 日。

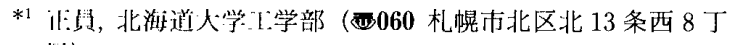
11).

*2 北游道大学经学部（西060 札幌市北区北 15 条西 7 丁目）
繰返し転がりーすべり接触を受けるUHMWPE平板 の変形挙動については明らかになったが, 実際の歩行 動作において人工膝関節中の UHMWPE は複雑な繰 返し負荷を受けており，摩耗を正確に評価するために は実際の歩行動作時の解析を行わなければならない.

実際の歩行動作条件における UHMWPE 関節板の 摩耗挙動については, いわゆる䎑シミュレータを用い た実人工㯟関節の摩耗実験 ${ }^{(5)(6)}$ が行われている。これ らの実験によりさまざまな形状の人工膝関節における 摩耗現象を再現, 観察することができる.しかし，その 摩耗現象をより詳細に検討するためにはUHMWPE 関節板内部での力学的挙動を考察する必要がある。ま た，膝シミュレー夕実験は過去に製作された人工膝関 節を用い，その形状や材質の比較には活用されるが， その結果の最適形状設計等への応用は多くのサンプル (人工膝関節) を必要とし，難しい。したがって本論文 では，実際の人工膝関節形状ならびに歩行動作による 荷重変動を考慮し, 人工膝関節におけるUHMWPE 関節板の変形挙動を繰返し塑性構成式を組込んだ弾塑 性有限要素法により解析し, 人工膝関節の最適設計の 一助としたい. 


\section{2. 繰返し接触変形解析}

$2 \cdot 1$ 繰返し塑性モデル(7) 本論文で用いた繰返 し塑性構成式について，以下に簡単に説明する。

温度 $T$ のもとでの繰返し負荷により，ひずみ硬化 が安定化する材料に対して賁荷関数 $f$ が次式で表示 できる。

$$
\begin{aligned}
f= & \frac{1}{2} C_{i j k l}\left(\sigma_{i j}-\alpha_{i j}\right)\left(\sigma_{k l}-\alpha_{k l}\right) \\
& -\frac{1}{3} R^{2}(\kappa, T)=0 \ldots \ldots \ldots \ldots . .
\end{aligned}
$$

ここで, $C_{i j k l}$ は塑性変形により誘起される 4 階異方 性テンソル係数, $\sigma_{i j}$ は応力テンソル, $\alpha_{i j}$ は降伏曲面 の中心を示す背応力テンソル, $R$ は流れ応力, $\varkappa$ は硬 化, 軟化のパラメータである.

塑性ひずみ増分が負荷面に垂直であるという仮定を 用いれば, 式（1）で示される負荷関数に関連する塑性 流れ則は次式となる.

$$
d \varepsilon_{i j}^{p}=\frac{3}{2} \frac{d \bar{\varepsilon}^{p}}{R} C_{i j k l}\left(\sigma_{k l}-\alpha_{k l}\right)
$$

上式中の $d \varepsilon_{i j}^{p}, d \bar{\varepsilon}^{p}$ はそれぞれ塑性ひずみ増分テンソ ル，相当塑性ひずみ増分である.

背応力の移行式として, 背応力増分 $d \alpha_{i j}$ の方向が各 瞬間の背応力 $\alpha_{i j}$ と負荷点 $\sigma_{i j}$ を結ぶ径べクトルに一 致するとした Prager-Zieglerの仮定を用いると, こ の場合の背応力増分は次の式で表示できる.

$$
\begin{aligned}
& d \alpha_{i j}=\frac{3}{2 R^{2}}\left[C_{k l m n}\left(\sigma_{m n}-\alpha_{m n}\right) d \sigma_{k l}\right] \\
& \quad \times\left(\sigma_{i j}-\alpha_{i j}\right)-\left(\frac{d R}{d W^{p}}\right)\left(\sigma_{i j}-\alpha_{i j}\right) d \bar{\varepsilon}^{p}
\end{aligned}
$$

ここで， $d W^{p}$ は塑性仕事増分である。 また，硬化，軟 化のパラメータ は次式で表示できる。

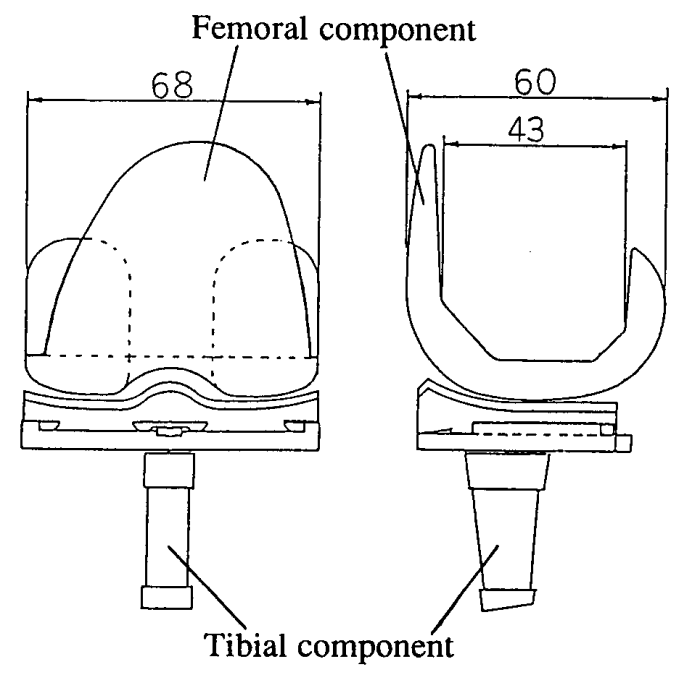

図 1 後十字䩲带温存型人工膝関節（LFA-III）

$$
d \varkappa=d W^{p}=R d \bar{\varepsilon}^{p}=\left(\sigma_{i j}-\alpha_{i j}\right) d \varepsilon_{i j}^{p}
$$

また，繰返し負荷を受ける場合の応力ーひずみ関係は， 降伏曲面の中心移動を考慮した次式の Ramberg-Osgood 則で表示される.

$$
\varepsilon_{t}-e_{t}=\frac{\sigma_{t}-\alpha_{t}}{E}\left[1+K\left(\frac{\sigma_{t}-\alpha_{t}}{\sigma_{0(n)}}\right)^{m_{(n)}}\right]
$$

ここで, $\varepsilon_{t}$ は単軸ひずみ, $\sigma_{t}$ は単軸応力であり, $e_{t}$, $\alpha_{t}$ はそれぞれ降伏曲面の中心のひずみと応力である. また, $K, E$ は定数と縦弾性係数である.さらに, $\sigma_{0(n)}$, $m_{(n)}$ は $(n-1)$ 回の負荷履歴を受けたあとに $\varepsilon_{0}$ の永 久ひずみを生ずるときの伈力と硬化指数であり, 硬化 安定材に対して次式で表示できる.

$$
\begin{aligned}
& \sigma_{0(n)}=\sigma_{0(\infty)}\left\{1-\alpha \exp \left(-\frac{W_{(n-1)}^{p}}{W_{0}}\right)\right\} \\
& m_{(n)}=m_{(\infty)}\left\{1-\beta \exp \left(-\frac{W_{(n-1)}^{p}}{W_{1}}\right)\right\}
\end{aligned}
$$

ただし，本解析では UHMWPE が高分子材料である ことを考慮し， $\varepsilon_{0}$ を $2.5 \%$ 塑性ひずみとした。また， 流れ応力 $R$ も同様に次式で表示できる。

$$
R=R_{(\infty)}\left\{1-\lambda \exp \left(-\frac{W^{p}}{W_{2}}\right)\right\}
$$

式 $(8)$ で $W^{p}=W_{(n-1)}^{p}+\Delta W^{p}$ であり, 現変形段階での 塑性仕事である. また, 式 $(6) \sim(8)$ で， $\sigma_{0(\infty)}, \alpha, W_{0}$, $m_{(\infty)}, \beta, W_{1}, R_{(\infty)}, \lambda, W_{2}$ は, それまでに受けた負荷履 歴に依存する材料定数である。

前報(3)(4) と同様に, UHMWPE 材は等方性材として 取扱う。等方性材の場合, 平面ひずみ状態において異 方性パラメータは以下のようになる。

$$
\left.\begin{array}{l}
C_{1111}=C_{2222}=C_{3333}=\frac{2}{3} \\
C_{1122}=C_{2233}=C_{3311}=-\frac{1}{3} \\
C_{1212}=\frac{1}{2}
\end{array}\right\}
$$

また, 3 種類のひずみ振幅を変えたUHMWPEの繰 返し引張一圧縮試験を行い, この実験結果と式 (2) 〜（8)を用いた計算機シミュレーションにより, UHMWPE の材料定数が以下のように求められる(3).

$$
\begin{aligned}
& \sigma_{0(1)}=15.0[\mathrm{MPa}], \quad m_{(1)}=3.0 \\
& \sigma_{0(\infty)}=18.5[\mathrm{MPa}], \quad m_{(\infty)}=2.2 \\
& R_{(\infty)}=9.55+1.69 \Delta \varepsilon^{p}[\mathrm{MPa}] \\
& \alpha, \beta, \lambda=0.0, \quad W_{0}, W_{1}, W_{2}=1.0[\mathrm{MPa}]
\end{aligned}
$$

ただし，塑性ひずみ振幅 $\Delta \varepsilon^{p}$ は\%で表す。

$2 \cdot 2$ 解析モデル 解析対象とする人工膝関節は, 現在最も多く使用されている表面置換型の人工膝関節 とした。表面置換型においてもさまざまなタイプのモ デルが存在するが, 本論文では, 著者の一人によって 
開発された後十字靱帯温存型人工滕関節 (LFA-III) と した，図 1 に本人工滕関節の形状を示す。本人工滕関 節の大腿骨コンポーネントはアルミナ・セラミック製 で，二つの顆部の関節面の間には後十字靶帯を残すた めの等間が存在する。接触面形状は矢状断面に扔いて 前部，中央部，後部でそれぞれ異なる曲率半径を有し ており，中央部の曲率半径が最も大きい. 前額断面に 扔いては内外顆それぞれの中央部にわずかな平坦部を 持つが，㯲の内外仪時に局所的な当たりを防ぐために， 両顆の外側は米坦部から滑らかに推移する比較的大き な曲率半径を有する形状になっている。また，脛骨側 コンポーネントは中央部に固定用のステムを有するチ タン合金製トレイと UHMWPE 製の関節板より成り, 後方には後十字鞀带を温存するための切り込みを有す る. UHMWPE 製関節板の接触面形状は，前額面では 大腿骨コンポーネント断面形状を側方に広げた形状を しており，矢上:面では中央部から後方にかけて平坦で, その前方に平圤部より滑らかにつながる隆起部が設け られている。この阔コンポーネントの接触面形状によ り，大腿骨コンポーネントの回旋と，滕の大きな可動 域を得るための, 沝の届曲角度が大きいときの大腿骨 コンポーネントの後方への移動（Roll Back Movement）が可能になっている.

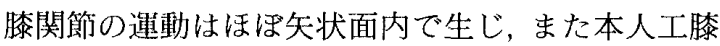
関節はほほ同形状の外顆ならびに内顆を持つので, 解 析を行うに当たり，その動きを二次元平面ひずみ状態 にモデル化した。図 2 に解析に用いた UHMWPE関 節板の二次元有限要素モデルを示す。解析要素として 8 節点アイソパラメトリック要素を用い, 2253 節点,

\section{表 1 材料定数}

Alumina ceramic UHMWPE

\begin{tabular}{lrrrr} 
Young's modulus E(MPa) & 350000 & 900 \\
Poisson's ratio $\nu$ & 0.2 & 0.4 \\
\hline
\end{tabular}

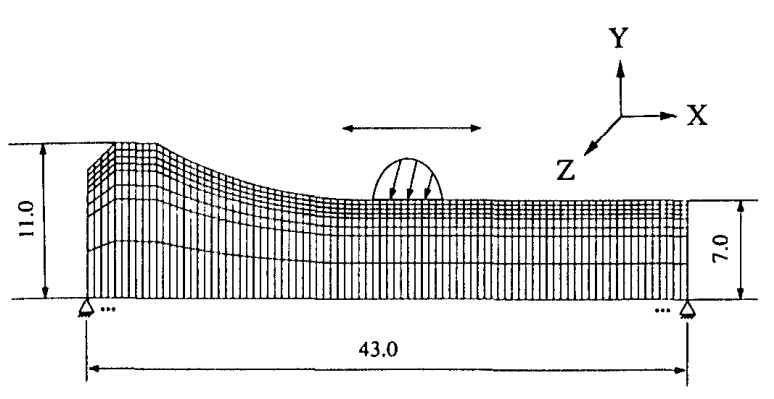

図 2 有限要素モデル
688 要素を有しており, 最小メッシュは $0.5 \mathrm{~mm} \times 0.3$ $\mathrm{mm}$ である。本人工膝関節に扔いて UHMWPE 関節 板はその下部のチタン合金トレイに固定されているの で，境界条件としては，UHMWPE関節板下面におい て全面固定とした。また，解析に用いた材料定数を表 1 に示寸。後述する単純押込み解析で使用するUHMWPEの弾塑性応力ーひずみ曲線は繰返し塑性構成 式中で用いられている初期材のものと同一であり，以 下の Ramberg-Osgood 則で与えられる。

$$
\varepsilon=\frac{\sigma}{E}\left[1+K\left(\frac{\sigma}{15.0}\right)^{3.0}\right], \quad K=0.00167 E
$$

$2 \cdot 3$ 解析方法 接触により UHMWPE 関節板 が大腿骨コンポーネントより受ける接触圧力分布は, 前報(4) と同様にあらかじめ弾塑性有限要素法（汎用非 線形構造解析プログラム MARC K-5）の接触解析機 能を用い, 大腿骨コンポーネントと脛骨コンポーネン 卜 (UHMWPE 関節板) 間の単純押込み時の接触圧力 分布を求め，この圧力分布を垂直荷重，さらに摩擦係 数 $\mu$ による摩擦力を水平荷重として, これらの荷重を UHMWPE 関節板上を連続的に移動させることによ り実際の歩行を表現した。なお，本解析において摩擦 係数は $\mu=0.1^{(8)}$ とし， 5 回めの歩行サイクルまで, 順 次解析を行った。本解析は UHMWPE 関節板の摩耗 挙動における初期変形段階を解析することになるが, 基本的には繰返し接触による摩耗は初期の変形挙動が 連続して繰返し生じることによりクラックを生じ，そ れが摩耗へと進展していくと考えられるので, 本解析 結果より摩耗に対する影響を考察できる。

$2 \cdot 4$ 接触圧力分布 歩行動作により UHMWPE 関節板の受ける接触圧力は変動し，その值は歩行時に おける大腿骨ならびに脛骨コンポーネント間の変動負 荷と相対位置により与えられる，両コンポーネント間

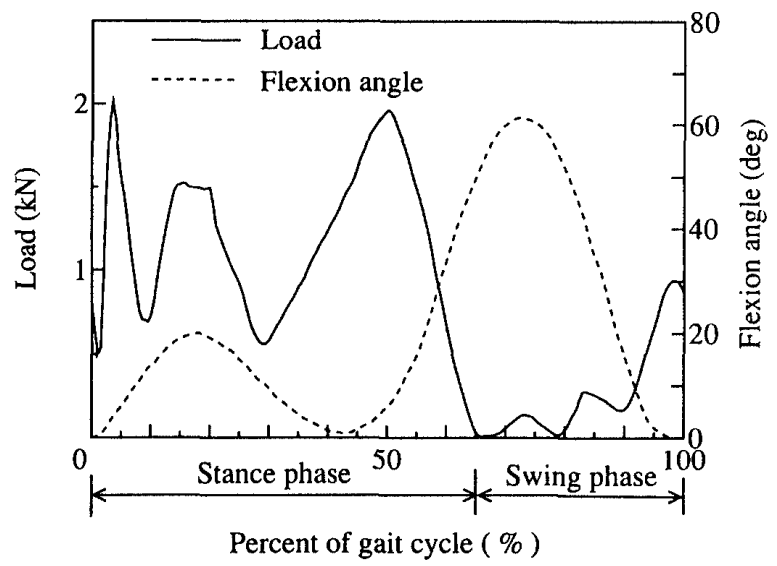

図 3 歩行サイクルに対する UHMWPE 関節板の 受ける荷重ならびに膝屈曲角度の変化 
の変動負荷としては図 3 に示す Morrison ${ }^{(9)}$ による通 常歩行時の荷重変動を用いた. 両コンポーネントの相 対位置は回転成分と並進成分, つまり膝の屈曲角度と 両コンポーネントの前後方向の位置関係（大腿骨コン ポーネントの最下点上から見た脛骨コンポーネントの 前方変位量として表現する）により決定される，滕屈 曲角度は図 3 に示すようにDouble Knee Action と呼 ばれる二峰性の変化を示す(10). また, 脛骨コンポーネ ントの前方変位量に関しては各人工膝関節の接触面形 状によりその動きが大きく異なるので, 本人工膝関節 における膝屈曲角度と前方変位量の関係を X 線写真 より求めた。図 4 にその結果を示す. 図中の○印なら びに $\square$ 印は X 線写真より求めた実験点であるが, こ れらの点は撮影時の撮影角度の影響ならびに読取り時 の誤差により, 角度, 前方変位量ともに数度または数 $\mathrm{mm}$ の誤差を含んでいる。また実線は, 脛骨コンポー ネントは常に後方に移動しようとしているとの仮定の もとに, 兩コンポーネントの干渉位置ならびに後十字 靱帯の存在を考慮して計算した前方変位量である。著 者らの一人の実験(11)によっても脛骨コンポーネント はほぼ常に後方へ移動する力を受けていると考えら れ，実験点の誤差も考慮すると上記の仮定による実線 の動きはほぼ正しいと考えられる。したがって, 本論 文では脛骨コンポーネントの前方変位量として,この 計算值を用いた。

繰返し接触変形解析に用いる接触圧力分布として は, 図 3 に示す 1 歩行サイクルを 200 分割し, それぞ れの状態における単純押込み時の接触圧力分布を求め た。な扔接触圧力の計算の際に, 本論文では実際の人 工膝関節を二次元平面ひずみ状態にモデル化を行い, モデル厚さつまり前額断面における接触幅を 7.11 $\mathrm{mm}$ 一定と仮定した。実際の UHMWPE 関節板は接

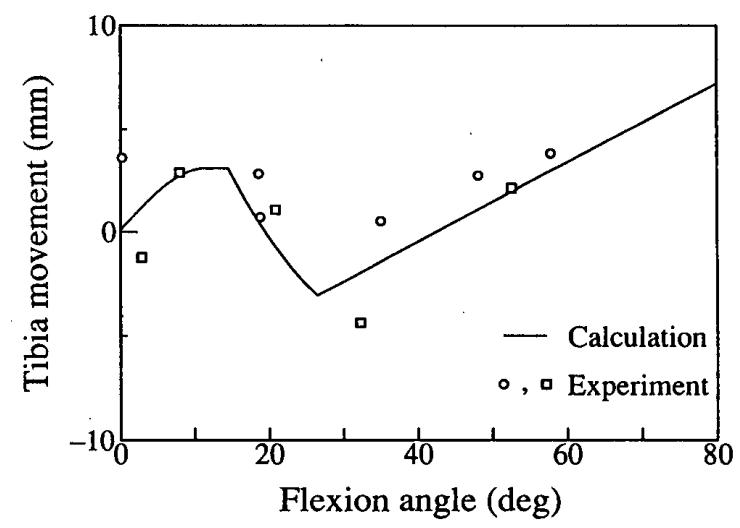

図 4 膝屈曲角度に対する脛骨コンポーネント 前方変位量の変化
触より三次元的な変形を生じ, 両コンポーネントの接 触面形状によりその前額断面接触幅は無負荷時で 6.0 $\mathrm{mm}$, 最大荷重時では $11 \mathrm{~mm}$ 程度まで広がるが, 上記 の接触幅 $7.11 \mathrm{~mm}$ 一定の仮定により本モデルによる 解析結果は荷重の大きい部分においてより大きな荷重 を見積もった結果となる，つまり，危険サイドの条件 を考慮した解析になっている.

図 5 に歩行サイクルの $5 \%$ ごとの接触圧力分布の計 等結果を示す. 図中, UHMWPE 関節板モデルの上に 載っている半円状のものは大腿骨コンポーネントの接 触部モデルで，この両コンポーネントが接触している 領域において大腿骨コンポーネント内に黒く示されて いるのが接触圧力分布である.これらの図より，200 分 割されたそれぞれの状態では，接触面の形状も荷重も
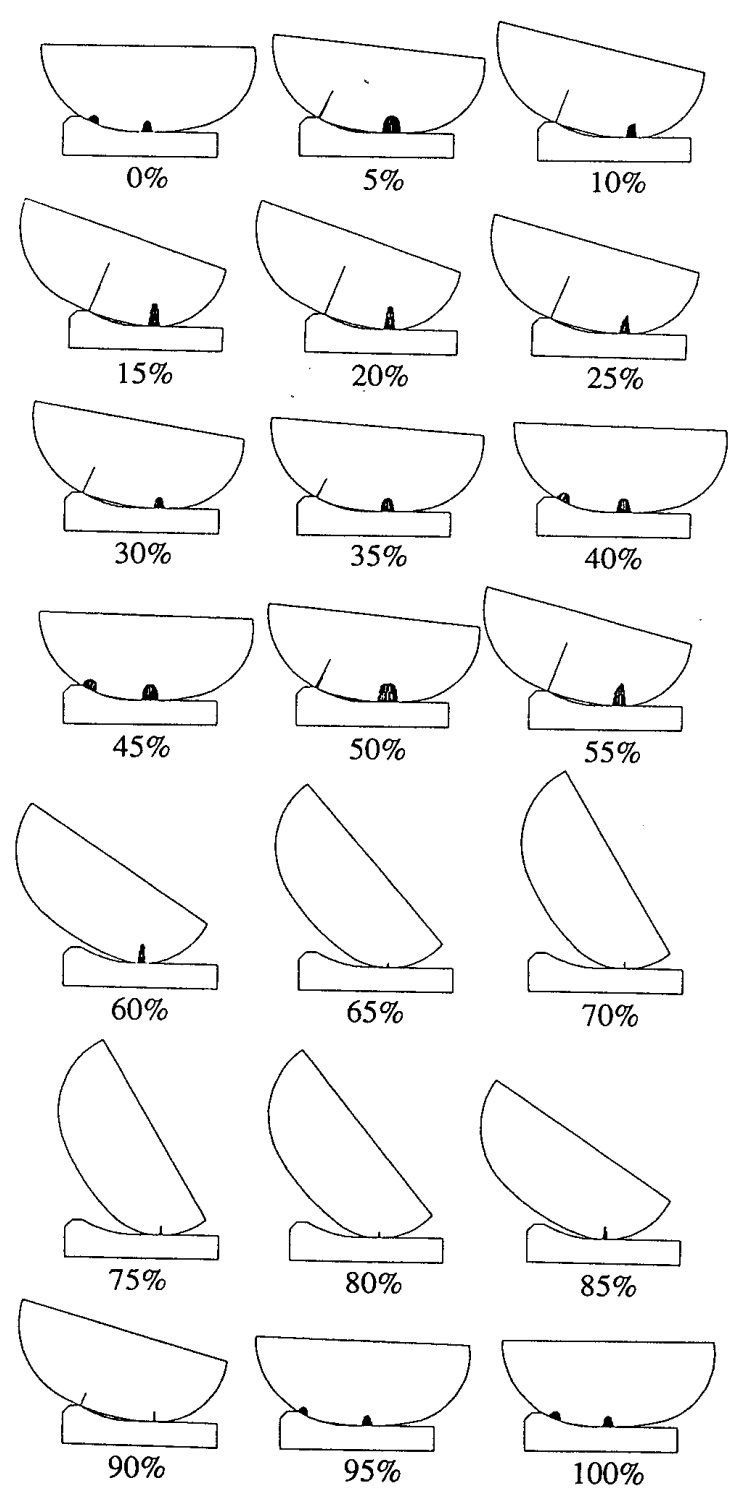

図 5 步行サイクルの各状態における 単純押込み解析結果 
異なるため接触压力分布も大きく異なることがわか る。また, 大腿愲コンポーネントとUHMWPE 関節板 前方隆起部との干渉が生じている歩行サイクル $55 \%$ までは，関節板前方隆起部上端近くと関節板平坦部の 2 筒所で接触が生じている，特に前方隆起部最上部で はロ部で接触するので非常に大きな接触圧力を受けて いる。

2.5 解析結果および考察 図 6 亿歩行サイクル 1, 5 回終了特の変形図を示す。破線嵮荷を受ける前 の要素を示し, 実線は負荷を受けた後の変形した要素 を示す．変形搔は $X$ 軸， $Y$ 軸方向ともに 20 倍に拡大 している. 1, 5 サイクル終了時の両変形図より, UHMWPE 関節板的前方隆起部の上方と隆起部直後の平 坦部分の 2 領域での変形が大きくなっている。つまり 本人几㯟関節に扔いて, UHMWPE関節板はこの 2 領域に扔いて集中的な負荷を受けていることがわか る.

接触により UHMWPE 関節板が受ける最大応力履

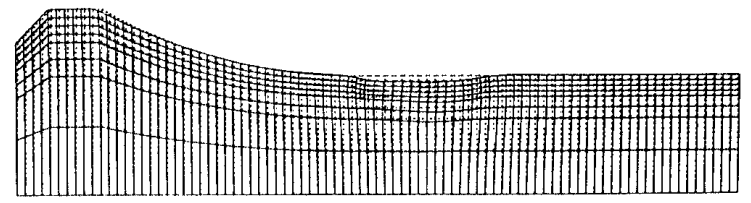

(a) 1 サイクル終了時

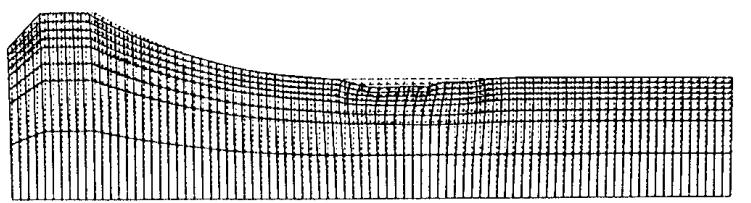

(b) 5 サイクル終了時

図 6 変形図

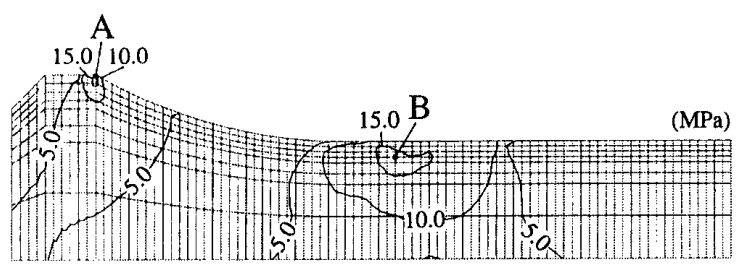

(a) 第 1 サイクル中

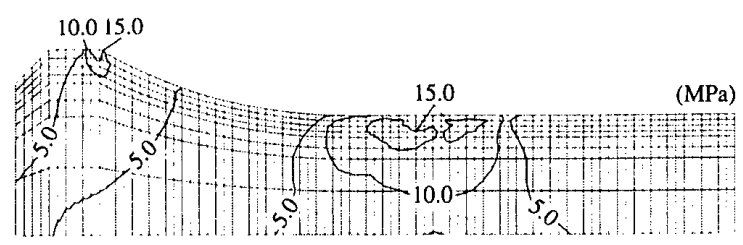

(b) 第 5 サイタル中

㲸 7 最大相当纫力分布図
歷を評価するために，図 7 に第 1 ，第 5 サイクル中に 生じる各節点に抢ける最大相当応力の分布を示す，各 サイクル中に抢ける最大相当応力は図 6 で示された変 形の大きな 2 領域を中心に分布している。 この二つの 接触領域に㧈けるそれぞれの最大值は, 前方隆起部領 域では関節板表面に, 平坦部領域で㹥表面より $1 \mathrm{~mm}$ 程度内部で生じていることがわかる．また，サイクル の違いによる最大相当応力分布の変化は, 二つの接触 領域に扔いて最大值を生じる点近傍での応力值が若干 増加することを除けばほとんど変化が見られない。こ れらの結果より, 前方隆起部領域では, UHMWPE 関 節板表面に，また平坦部領域ではその内部に心力振幅 の大きいところがあるため，それぞれの場所でUHMWPE が塑性疲労破壊を起こし, 摩耗粉の原因とな る微小クラックを発生すると考えられる。

図 7 に示した最大相当応力の発生をより詳しく評価 するために，二つの接触領域中でそれぞれの最大相当 応力を生じる点 $\mathrm{A}$ ならびに点 $\mathrm{B}$ における第 1 サイク ル中の相当応力の変化を図 8 に示す．図上り，両点と もに歩行サイクル中に相当応力は大きく変動してお り，その変動幅は同程度で，二つの接触領域で荷重を 分割して受けていることがわかる．またとの最大值は 歩行サイクルの約 15-25\%で発生し，約 10-15\%なら びに約 50-60\%の位置でも大きな值を示している。こ の相当応力の変化と図 3 に示した UHMWPE 関節板 の受ける荷重の変化を比較してみると, 大まかな変動 の様子は一致しているが，それぞれの最大值の発生位 置は同じではない，本人工膝関節の大腿骨コンポーネ ントの矢状断面形状は前述のように三つの曲率で構成 されており，滕屈曲角度が小さい場合には最も大きな 曲率半径部分で接触し，さらに図 5 に示されているよ うにその前方領域において UHMWPE 関節板の角部 で接触するのではなく面で接触するため，これらによ

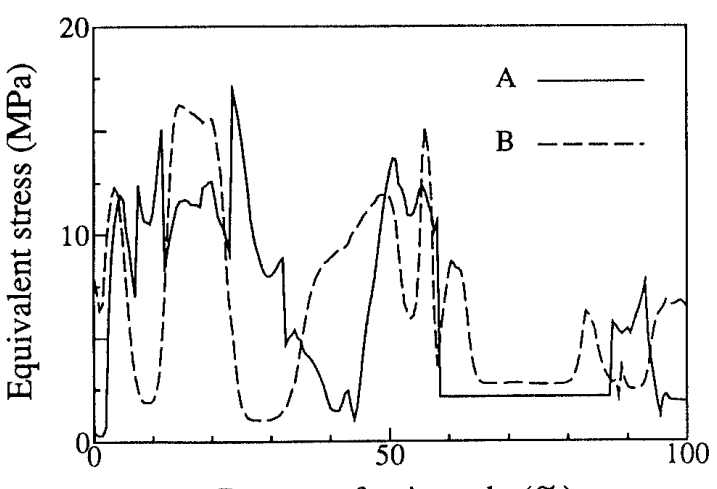

Percent of gait cycle (\%)

図 8 第 1 サイクル中に招ける相当応力の変化 
り接触面積が大きくなり接触圧力が小さくなる．図 3 より, 最大荷重発生位置における㯟屈曲角度はかなり 小さな值であるので, この影響により両者の最大值発 生位置は対応していない. 逆に, 歩行サイクルの約 $15^{-}$ 25\%および約 55-60\%の領域では膝屈曲角度が大きく なり，これにより大腿骨コンポーネントの接触位置が 曲率半径の小さい部分に移行するため, 最大荷重点に きおける相当応力より大きな応力を生じている，また Roll Back Movement が生じる歩行サイクルの約 $60 \%$ 以上の領域においても大腿骨コンポーネントの接 触面曲率半径が小さくなるが，この領域は遊脚期にあ たり荷重も小さくなるため，相当応力としては小さな 值になっている。

実際の摘出された人工膝関節の分析 ${ }^{(12)}$ ，ならびに人 工㯟関節を想定した UHMWPE 関節板の摩耗実験(13) では, UHMWPE 関節板の 1-2 mm 程度内部の位置 で材料の疲労により生じた摩耗と, UHMWPE関節 板表面での摩耗との雨方が兒られる，関節板表面で生 じる摩耗については, 本人工膝関節のような UHMWPEを用いた表面置換型の人工膝関節では, 歩行 動作時に両コンポーネント間の潤滑状態が弾性流体潤 滑状態になっておらず，混合潤滑状態である(14)ので， 大腿骨コンポーネントと UHMWPE 関節板表面が直 接接触し，関節板表面で UHMWPE の凝着や疲労が 生じる(15)ことにより表面に微小クラックが発生し， これらが進展し摩耗粉になり ${ }^{(13)}$, 摩耗が進行してい く．材料表面における微視的なクラックの発生機構は 明らかではないが, 巨視的な変形機構の観点より, UHMWPE 関節板に発生した微小クラックを進展さ せる要因として，微小クラック発生位置における引張 応力（モード I 破噮）ならびにせん断応力（モード II

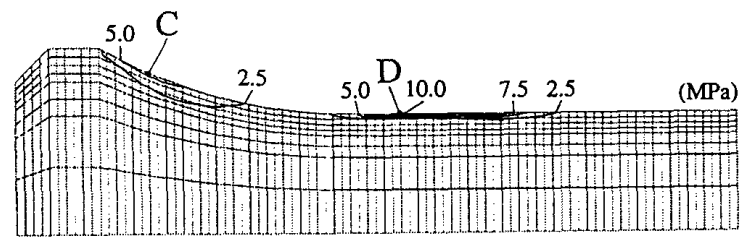

(a) $X$ 軸方向応力

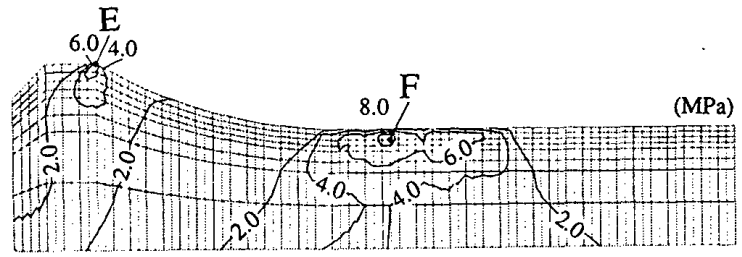

（b）せん断応力（絶対值）

図 9 第 1 サイクル中における最大応力分布図
破壊)の影響が考えられる.ただし，本解析において $Y$ 軸方向の応力は常に圧縮の値を示すので, 引張応力の 影響が考えられるのは $X$ 軸方向の応力のみである。

これらの影響を調べるために, 図 9 に第 1 サイクル 中に生じる $X$ 軸方向応力, ならびにせん断応力の最 大值の分布を示す。ただし，せん断応力は正方向と負 方向の両方が考えられるので, 絶対值の最大值とし た。これらの分布は, 前述の最大相当応力分布と同様 にサイクルの違いによる変化はあまり見られなかった ので，第1サイクル中の結果のみを示した．前報(4) らびに Bartel ら(16)によっても示されているように， 本人工膝関節においても UHMWFE 関節板は接触し ている 2 領域において，その表面で引張りの応力を受 けている。一方，最大せん断応力の分布は図 7 の最大 相当応力の分布に似た分布を示し，前方隆起部領域で は関節板表面で最大值を，また平坦部領域では関節板 内部で最大值を示している。したがって, UHMWPE の塑性疲労破壊により発生した微少クラックはせん断 応力によるモードII 破壊の影響を，また接触により UHMWPE 関節板表面に発生した微少クラックは引 張応力によるモード I 破壊の影響をより大きく受け，

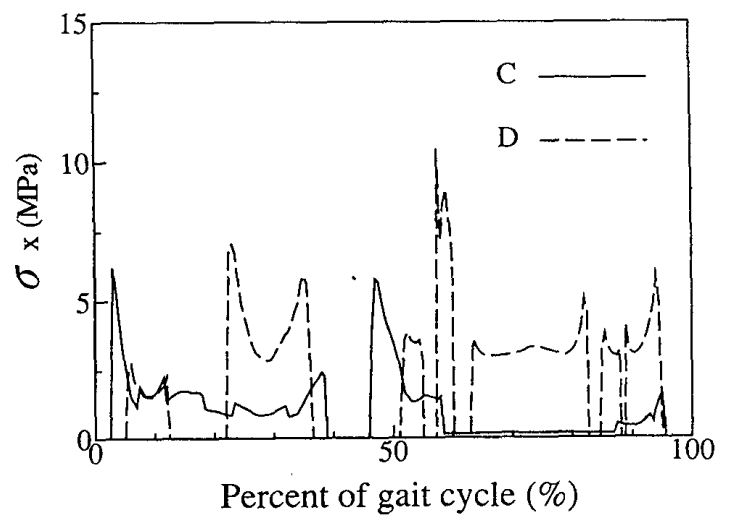

(a) $X$ 軸方向応力

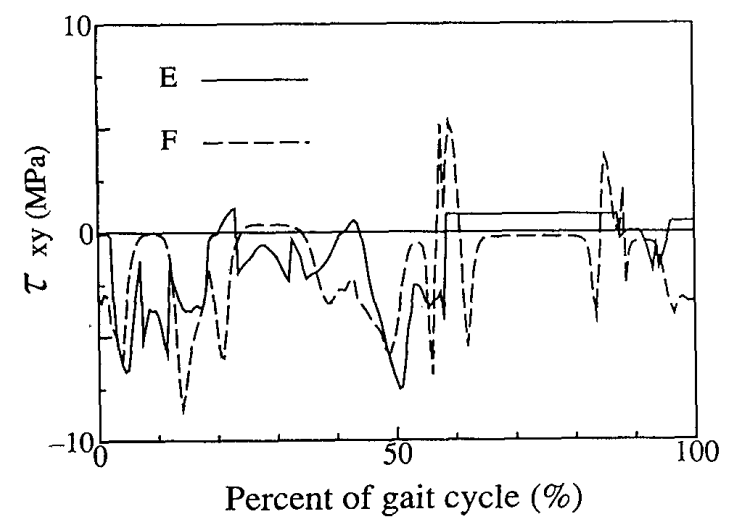

(b) せん断応力

図 10 第 1 サイクル中に扔ける応力の変化 
より大きなクラックに進展していくと考えられる。

それぞれの念力のサイクル内に扔ける変化を詳細に 検㰾与るために，睬 9 に扔いて大きな応力值を示す点 C，D，E，Fにおけるサイクル内の応力値の変化を図 10 に亦す. ただし， $X$ 軸方向応力については引張応力 のみが問題となるので, 正の值のみを示した， $X$ 軸方 向応力は着门点の断面、に莎重が存在する間は压縮応 力となるが，それをはずれると引張応力となり，特に その境界での佔が大きくなっている，また，その最大 值は歩行けイクル約 55-60\%の位置で発生している。 せ九断夋力も衍重の移動により 1 歩行サイクル中に数 回の符青変化を伴う繰返しせん断になって扔り, 歩行 サイクル約 15 20\%ならびに約 50-60\%の領域内で大 きな値を生じている。

汹8ならびに図 10 ではUHMWPE関節板中の最 大匛発本:估莦に打ける応力の変動を示した。これに よりその者川点に扔ける応力履祡を評価することはで きたが，1少行サイクル中に恃荷重が移動することに より最大の㚇ノが発生する位惪も変動するため, これ らの应怩以必らずしもその時点の応力の最大值は含 まれていない。したがって，UHMWPE 関節板全体が 受けている仙牌歴として, 図 11 に 1 歩行サイクル を200 分制した各時点に扔ける応力の最大值の変動を 示す。濦上り, 相当応力, $X$ 軸方向引張応力, 世ん断 応少ともに问様な変動を示し，これらの值は前述の㯟 屈罒们度が大きくなる歩行开イクルの約 15-25\%なら びに約 50-60\%の領域で大きな值を示していることが わかる.また，接触により UHMWPE 関節板表面に生 じる微小クラックの発生原因として, UHMWPEの 凝䒴，疲学ならびに微視的な塑性変形等が考えられる が，これらの装恻はすべて接触压力の大きさに比例し て微小タラックの発生を加速すると考えられる。これ についても図3 を見ると歩行サイクル約 15-20\%なら びに約 55\%の位瑟で大きな接触圧力を生じて扔り，こ

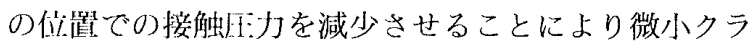
ック発生毛抑元られる。

\section{3. 結 言}

步行動作㭙における人工膝関節中のUHMWPE 関 節板の)接触变形挙動を, 繰返し塑性構成式を用いた弾 塑性冾限整素法により解析し, UHMWPE 関節板の 受ける小学似状態ならびにその摩耗に対する影響につ いて妨祭した。その結果を以下にまとめる。

（1）本人工膝関節では，両コンポーネントの接触 面形状により接触位圆があまり移動せず, UHMWPE 関節板はをの前方隆起部の上方と隆起部直後の平坦部

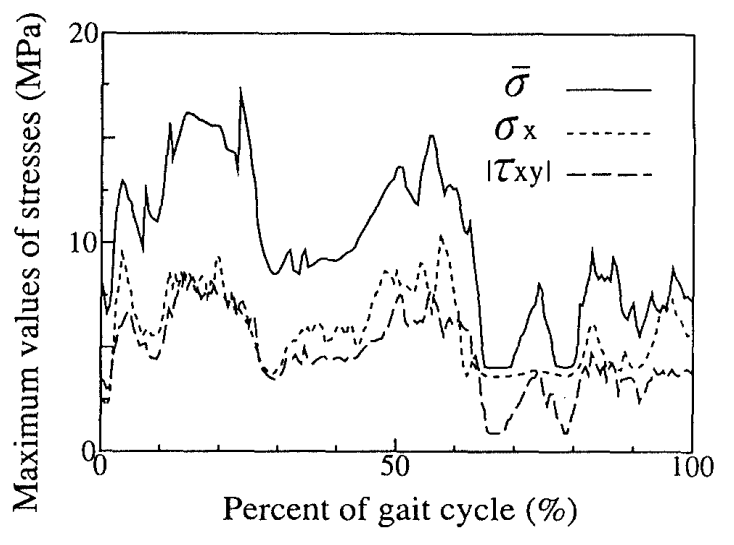

图 11 第 1 サイクル中における各応力の最大值の変化

分の 2 領域で局所的な変形を受ける.またその領域内 に扔いても, 歩行動作によりUHMWPE関節板の受 ける応力状態は複雑に変動している。

（2）UHMWPE 関節板前方隆起部領域において は, UHMWPEの疲労による微小クラックの発生に 関与している最大相当応力履歴, つまりひずみエネル ギー履歷，ならびに発生した微小クラックを進展させ る $X$ 軸方向引張応力, せん断応力すべてが関節板表 面で最大になる。したがって，この領域においてUHMWPE 関節板の摩耗は関節板表面より生じる.

(3) 一方，平坦部領域では，相当応力とせん断応 力は UHMWPE 関節板内部の深さ約 $1 \mathrm{~mm}$ の位置で 最大になるが, $X$ 軸方向引張応力は関節板表面にの み生じている。また関節板表面には，内部ほどではな いがせん断応力も生じている。したがって，この領域 に扔けるUHMWPE 関節板の摩耗を評価するために は，この両位置における挙動を考慮しなければならな w.

（4）本人工膝関節に扔いて, UHMWPE関節板 の摩耗に関連していると考えられる応力ならびに接触 圧力は, 接触面形状の影響により最大荷重時に最大值 にならず，歩行サイクルの約 15-25\%扔よび約 50$60 \%$ の位置, すなわち大腿骨コンポーネントの接触面 が曲率半径の小さい部分に変化する膝屈曲角度約 1520 度の状態で大きな值を示す。つまり，人工膝関節の 接触面形状は UHMWPE 関節板に生じる応力に密接 に関係していることがわかった。

終わりに，本研究の計算に協力いただいた日本電気 (株) の村松英路氏（当時北海道大学大学院生）に謝意 を表す.また, 本研究の一部は, 文部省科学研究費補助 金重点領域研究「バイオメカニクス（No. 04237101）」 の補助によることを記して深謝する。 


\section{文献}

(1) 山本, 潤滑, 31(1986), 775.

(2) 康本・牛田, 機械研二ュース, $\mathbf{5}(1993), 6$

(3) 藤木・ほか 2 名, 機論, 59-567, A (1993), 2800.

(4) 藤木・活か 2 名, 機論, 60-571, A(1994), 833.

（5）宮城・ほか2 名, 日関外誌, IV-(4) (1988)，603.

(6) Rose, R. M., 活 3 名, J. Biomed. Mat. Res., 18(1984), 207.

（7）石川・佐々木, 機論, 53-491, A (1987), 1432.

(8) McKellop, H., ほか 3 名, J. Biomed. Mat. Res., 15(1981), 619.

(9) Morrison, J. B., Bio-Med. Eng., (1968), 164.
(10) Lafortune, M. A., ほか 3 名, J. Biomech., 25(1992), 347.

(11) Yasuda, K. and Sasaki, T., Clin. Orthop., 220(1987), 266.

(12) Engh, G. A., ほか 2 名, J. Bone Joint Surg., 74-B(1992), 9.

(13) Blunn, G.W., ほか 3 名, Clin. Orthop. \& Related Res., 273(1991), 253

(14) Murakami, T., ほか3 名, Proc. 19th Leeds-Lyon Symp. on Tribology, (1992), 673.

(15) Atkinson, J.R., 浮 2 名, Trans. ASME, J. Lubr. Technol., 100(1978), 208.

(16) Bartel, D. L., ほか3名, Trans. ASME, J. Biomech. Eng., 107 (1985), 193. 